\title{
Farmers Perception on Fungicide Use for Developing Sustainable Environment and Conservation of Biodiversity: A Study in Cooch Behar District of India
}

\author{
Ganesh Das* \\ Subject Matter Specialist (Agricultural Extension), Uttar Banga Krishi Viswavidyalaya
}

Received: September 08, 2016; Accepted: September 27, 2016; Published: October 18, 2016

*Corresponding author: Ganesh Das, Subject Matter Specialist (Agricultural Extension), Cooch Behar Krishi Vigyan Kendra, Uttar Banga Krishi Viswavidyalaya, Pundibari, Cooch Behar, India, Phone: 8967786990; Email: ganesh.ext@gmail.com

\begin{abstract}
Fungicide was essential for control of infestation of fungus on different crop. Farmers were use different type of fungicide on crop field. Their perception on fungicide use may be different. Different government and private organisation took initiative to aware the farmer about the use of fungicide. But still a problem was found by Cooch Behar Krishi Vigyan Kendra that farmer perception of fungicides use were not homogeneous and the different sources of information may be use by the farmers for fungicide application. So a study was conducted at Gopalpur village in Cooch Behar district, West Bengal, India to know the farmer perception on fungicide use and sources of information utilize for fungicide application. The data were collected during June, 2016. The research design was followed in the study was survey research method. The sample size of the study was 100 .The dependent variable of this study was perception and independent variables were age, gender, number of family member, caste, land holding, education, annual income and sources of information. The descriptive statistics like frequency, percentage, Pearson's product moment correlation and other statistical tools were used for the investigation. This study had shown the relation of the perception of fungicide use with the different independent variable and the role of different extension mechanism for fungicide information providing. It was concluded from the study that farmers' perception of fungicide use were not homogeneous and the different socio-economic variable may affect the perception of the farmers on fungicide use.
\end{abstract}

Keywords: Fungicide; Perception; Information; Aware

\section{Introduction}

Harmful fungus control without any fungicide cannot meet the increasing crop production in India. One of the reasons is due to the increasing the infestation of fungus attack on crop filed. So requiring diseases management effectively to increase the amount of producing crop can satisfy a large demand in the Indian market. Use of chemical fungicide is one of the popular and effective ways to control the fungus infestation. Farmers may use one or more fungicide. Farmers' preference of the fungicide may not be equal. There are several types of harmful fungus diseases on crop field. Some sociological and economical factor may influence on the perception on use of fungicide. Farmers of Cooch Behar district were more interest to used fungicide on agriculture field. Agriculture production of Cooch Behar district was increased due to use of fungicide and other modern technology. However, besides the benefits that it brings, fungicides potentially affect the health of users and the surrounding environment. If not used properly, fungicide cause human poisoning and is accumulated as residues in food and the environment, which result in the variety of human diseases, environmental pollution and loss of biodiversity. Different government and private organization took initiative to aware the farmer aware on safe use of fungicide by arranging different awareness and training program. But farmer Perception about fungicide used may be different. Cooch Behar Krishi Vigyan Kendra organized so many awareness and training programs on, safe use of fungicide at on campus and off campus. Farmers' perception of fungicide used was not homogeneous in Cooch Behar district. So a study was conducted to know the farmers' perception on fungicide use with respect to their socioeconomic and other variable. Anonymous concluded from their study that consumers' attitude is associated with the knowledge and personal experience they possess [1]. Farmers' perceptions of the characteristics of modern rice varieties significantly affected adoption decisions. Farmer characteristics among others include sex, age, education, and household size while institutional factors include farm size, membership to association, access to information, access to credit, and access to infrastructure such as roads or storage [2]. Educated farmers were believed to have higher ability to perceive, interpret and respond to new information about improved technologies than their counterparts with little or no education $[3,4]$. It was found from most of the studies that a positive relationship exist between access to credit and use of improved technologies and access to extension services and use of improved technologies [5-7]. Anonymous concluded from their study that most of the vegetable farmers perceived that frequency of insects and disease infestation had increased over the past 10 years and most of the pesticides belonged to high and moderate risk chemicals [8]. Anonymous found that farmer perceptions of toxicity level of chemicals they handle had not been found in conformity with the actual situation and they handle toxic chemicals thinking them to be safe [9] and 
Table 1: Classification of the respondent on the basis of different independent variable $\mathrm{n}=100$.

\begin{tabular}{|c|c|c|}
\hline Sl. No. & Variable & Number of respondent \\
\hline A. & Gender $\left(x_{1}\right)$ & \\
\hline 1. & Male & 65 \\
\hline 2. & Female & 35 \\
\hline B. & Age $\left(x_{2}\right)$ & \\
\hline 1. & $18 \mathrm{yrs}$ to $<25 \mathrm{yrs}$ & 20 \\
\hline 2. & 25 yrs to $<35$ yrs & 25 \\
\hline 3. & 35 yrs to $<50$ yrs & 40 \\
\hline 4. & $>50 \mathrm{yrs}$ & 15 \\
\hline C. & Education $\left(\mathrm{x}_{3}\right)$ & \\
\hline 1. & Illiterate & 10 \\
\hline 2. & Can read only & - \\
\hline 3. & Can read and write only & 20 \\
\hline 4. & Primary school & 30 \\
\hline 5. & Middle school & 20 \\
\hline 6. & High school & 15 \\
\hline 7. & Pre-university & - \\
\hline 8. & Graduate and above & 5 \\
\hline D. & Caste $\left(\mathrm{x}_{4}\right)$ & \\
\hline 1. & GEN(General) & 20 \\
\hline 2. & SC(Scheduled Caste) & 50 \\
\hline 3. & ST(Scheduled Tribe) & 20 \\
\hline \multirow[t]{2}{*}{4.} & OBC( Other Backward Classes) & 10 \\
\hline & Land holding (acre) $\left(\mathrm{x}_{5}\right)$ & \\
\hline 1 & Less than 2 & 30 \\
\hline 2 & $2-5$ & 40 \\
\hline 3 & $5-10$ & 20 \\
\hline \multirow[t]{2}{*}{4} & More 10 & 10 \\
\hline & Annual income level (INR) $\left(\mathrm{x}_{6}\right)$ & \\
\hline 1 & Less than Rs. 30,000 & 10 \\
\hline 2 & Rs. 30,001 -Rs. 60,000 & 15 \\
\hline 3 & Rs.60,001-Rs.1,00,000 & 25 \\
\hline 4 & Rs. $1,00,001$-Rs. $2,00,000$ & 35 \\
\hline 5 & Rs. $2,00,001$-Rs. $3,00,000$ & 10 \\
\hline \multirow[t]{2}{*}{6} & Rs. $3,00,001$ and above & 5 \\
\hline & Number of family member $\left(x_{7}\right)$ & \\
\hline 1 & Less than 5 & 65 \\
\hline 2 & More than 5 & 35 \\
\hline
\end{tabular}

greater number of the literate farmers had strong perception on the negative impacts of pesticides on soil, water, air and beneficial organisms [10].Perception as the process by which an individual maintains contact with the environment [11]. Land ownership and agricultural credit had positively impacted on pesticide use [12] and younger farmers were the most pesticides-effected group and well-targeted training programs [13]. The vegetable farmers in Tanzania were lack of appropriate knowledge on safe use of pesticides [14]. Anonymous showed that Non- Integrated Pest Management farmers used twice as many pesticides as IPM farmers and integrating rice-fish farming with IPM practices was a sustainable alternative to intensive rice mono-cropping in terms of an economic and an ecological point of view [15].
The study was conducted during June, 2016. The purpose of this study was to identify the farmer Perception on fungicide use with respect to their socio-economic variable.

\section{Material and Method}

The study was conducted at Gopalpur village, Cooch Behar district, West Bengal, India during June, 2016. Descriptive research design was used in this study. The data was collected by pretested well structured interview schedule. The respondents for this study were included from the farmers and farm women of Gopalpur village. Purposive sampling method was used for selection of village. Random sampling method was used for selection of the respondent. The sample size for the study was 100. The dependent variables of this study was perception and independent variables were age, gender, number of family member, caste, land holding, education, annual income and sources of information. There were fifteen number of perception statement were selected but after pre-test finally nine number of perception statement were selected. The variables were selected based on recommendation of the scientist of Uttar Banga Krishi Viswavidyalaya, Cooch Behar, West Bengal, India. The descriptive statistics like frequency, percentage and Pearson's product moment correlation were used for the investigation.

\section{Results and Discussion}

It was shown from the study that a majority of the respondent were male (65\%) farmer followed by female (35\%) farmer. It was shown that the majority percentage of the respondent age group belonged to 35yrs to <50yrs (40\%) followed by $25 y$ rs to $<35 y$ yrs $(25 \%)$. This type of age group may take more initiative to safe use of fungicide(Ntow et al. 2006).It was found that majority of respondent land holding size were 2 to 5 acre(40\%) followed by less than 2 acre (30\%). It was shown that majority of respondent were SC $(50 \%)$ category followed by ST $(20 \%)$ and GEN (20\%) category. It was observed that the majority percentage of the respondents Annual income level were Rs.1,00,001 to Rs.2,00,000 (35\%) followed by Rs.60,001Rs. $1,00,000$ (25\%). It was observed that the majority percentage of the respondents educational level were primary school (30\%) pass followed by middle school(20\%) pass and can read and write only $(20 \%)$. It was found from the study that majority of the respondents family size were less than 5 (65\%) followed by more than 5 (35\%). It was shown after investigation that majority of the respondent perception agree with the statement of "Prescribed dosages of fungicide application is best for control of fungus attack on crop field" (80\%) followed by "Mixing of fungicide is more effective" (45\%). It was found from the survey that majority of respondent perception were not agree with the statement of "Chemical fungicide is environmentally friendly" $(88 \%)$ followed by "Only used of fungicide can control the entire fungus attack of the field" (72\%). It was also found from the study that majority of respondent perception unknown with the statement of "Fungicide apply at the time of above ETL" (95\%) followed by "Fungicide is applied on the basis of agro climatic condition (70\%)". It was revealed from the survey that there exist a positive and significant association between the variable of land 
Table 2: Perception of the farmer on fungicide use $n=100$.

\section{Perception}

Bio diversity is affected by excess use of fungicide $\left(\mathrm{y}_{1}\right)$ Mixing of fungicide is more effective $\left(\mathrm{y}_{2}\right)$

Prescribed dosages of fungicide application is best for control of fungus attack on crop field $\left(\mathrm{y}_{3}\right)$

Only used of fungicide can control the entire fungus attack of the field $\left(\mathrm{y}_{5}\right)$

Fungicide apply at the time of above ETL (Economic Thresh hold level) $\left(\mathrm{y}_{5}\right)$

Chemical fungicide is environmentally friendly $\left(\mathrm{y}_{6}\right)$

Liquid form of fungicide is less affected the environment than Dust form of Fungicide $\left(\mathrm{y}_{7}\right)$

Fungicide is applied on the basis of agro climatic condition $\left(\mathrm{y}_{8}\right)$ frequency of fungus infestation has increased over the past 10 years $\left(\mathrm{y}_{9}\right)$

\begin{tabular}{|c|c|c|c|c|c|c|}
\hline \multicolumn{2}{|c|}{ Yes } & \multicolumn{2}{c|}{ No } & \multicolumn{2}{c|}{ Don't Know } \\
\hline Frequency & Percentage & Frequency & Percentage & Frequency & Percentage \\
\hline 40 & 40 & 20 & 20 & 40 & 40 \\
\hline 45 & 45 & 20 & 20 & 35 & 35 \\
\hline 80 & 80 & 17 & 17 & 3 & 3 \\
\hline 26 & 26 & 72 & 72 & 2 & 2 \\
\hline 5 & 5 & 0 & 0 & 95 & 95 \\
\hline 34 & 12 & 88 & 88 & 0 & 0 \\
\hline 20 & 20 & 10 & 10 & 70 & 70 \\
\hline 34 & 34 & 6 & 6 & 60 & 60 \\
\hline
\end{tabular}

Table 3: Fungicide dosage information used by the respondent $n=100$.

\begin{tabular}{|c|c|c|}
\hline Sources of information & Frequency & Percentage \\
\hline Agriculture office & 70 & 25 \\
\hline Own experience & 25 & 22 \\
\hline Other farmer & 22 & 95 \\
\hline Fungicide Retailer & 95 & 12 \\
\hline
\end{tabular}

Table 4: Association between personal and socio-economic traits with Perception of respondent $\mathrm{n}=100$.

\begin{tabular}{|c|c|c|c|c|c|c|c|c|c|c|c|c|c|c|c|c|c|c|c|}
\hline \multirow[t]{2}{*}{$\begin{array}{l}\text { SL } \\
\text { No }\end{array}$} & \multirow[t]{2}{*}{ Variable } & \multicolumn{18}{|c|}{ 'r' value } \\
\hline & & $Y_{1}$ & LOS* & $Y_{2}$ & LOS & $Y_{3}$ & LOS & $Y_{4}$ & LOS & $Y_{5}$ & LOS & $Y_{6}$ & LOS & $\mathbf{Y}_{7}$ & LOS & $Y_{8}$ & LOS & $Y_{9}$ & LOS \\
\hline 1 & $\mathrm{x}_{1}$ & 0.491 & 0.01 & 0.601 & 0.01 & 0.12 & NS** & 0.417 & 0.01 & 0.072 & NS & 0.206 & 0.05 & 0.504 & 0.01 & 0.174 & NS & -0.031 & NS \\
\hline 2 & $\mathrm{X}_{2}$ & 0.069 & NS & 0.011 & NS & 0.01 & NS & 0.261 & 0.01 & 0.07 & NS & -0.031 & NS & 0.307 & 0.01 & 0.247 & 0.05 & -0.546 & 0.01 \\
\hline 3 & $\mathrm{X}_{3}$ & -0.781 & 0.01 & 0.015 & NS & -0.54 & 0.01 & 0.113 & NS & -0.449 & 0.01 & 0.526 & 0.01 & -0.715 & 0.01 & -0.471 & 0.01 & 0.332 & 0.01 \\
\hline 4 & $\mathrm{X}_{4}$ & -0.021 & NS & -0.022 & NS & -0.1 & NS & -0.059 & NS & 0.05 & NS & 0.151 & NS & 0.0347 & NS & -0.024 & & -0.068 & NS \\
\hline 5 & $\mathrm{X}_{5}$ & -0.458 & 0.01 & -0.59 & 0.01 & 0.211 & 0.05 & 0.683 & 0.01 & -0.462 & 0.01 & 0.47 & 0.01 & -0.601 & 0.01 & -0.702 & 0.01 & -0.535 & 0.01 \\
\hline 6 & $X_{6}$ & -0.196 & 0.05 & 0.014 & NS & -0.044 & NS & 0.449 & 0.01 & 0.068 & NS & 0.205 & 0.05 & -0.089 & NS & -0.112 & NS & 0.417 & 0.01 \\
\hline 7 & $X_{7}$ & -0.688 & 0.01 & -0.621 & 0.01 & -0.054 & & 0.417 & & -0.312 & & 0.296 & 0.01 & -0.45 & & 0.105 & NS & -0.41 & 0.01 \\
\hline
\end{tabular}

*LOS: Level Of Significance

** NS : NON Significance

holding $\left(\mathrm{x}_{5}\right)$ and perception statement of $\mathrm{y}_{3}, \mathrm{y}_{4}, \mathrm{y}_{6}$ and negative and significant association of the perception statements of $\mathrm{y}_{1}, \mathrm{y}_{2^{\prime}}$ $\mathrm{y}_{5}, \mathrm{y}_{7}, \mathrm{y}_{8}$ and $\mathrm{y}_{9}$. The findings are line with the statement found by Rahman (2003). The variables caste $\left(\mathrm{x}_{4}\right)$ had no significant association with any of the perception statements. The variable gender $\left(\mathrm{x}_{1}\right)$ had positive and significant association with the statements of $\mathrm{y}_{1}, \mathrm{y}_{2}, \mathrm{y}_{4}, \mathrm{y}_{6}$ and $\mathrm{y}_{7}$. The variable age $\left(\mathrm{x}_{2}\right)$ had positive and significant association with the statements of $\mathrm{y}_{4}, \mathrm{y}_{7}$ and $\mathrm{y}_{8}$ and negative and significant association with the statement of $y_{9}$. The findings are line with the statement found by Adesina and Zinnah 1993. The variable education $\left(\mathrm{x}_{3}\right)$ had negative and significant association with the statements of $\mathrm{y}_{1} \mathrm{y}_{3}, \mathrm{y}_{5}, \mathrm{y}_{7}$ and $\mathrm{y}_{8}$ and positive and significant association with the statements of $\mathrm{y}_{6}$ and $\mathrm{y}_{9}$. The findings are line with the statement found by Lanyintuo and Mekuria 2005; Tabietal. 2010. The variables Annual income ( $\left.\mathrm{x}_{6}\right)$ had positive and significant association with the statements of $\mathrm{y}_{4}, \mathrm{y}_{6}$ and $\mathrm{y}_{9}$ and negative and significant association with the statement of $y_{1}$. The findings are line with the statement found by Feder et al. 1985 . The variables family size $\left(\mathrm{x}_{7}\right)$ had positive and significant association with the statements of $y_{4}$ and y6and negative and significant association with the statements of $y_{1}$, $\mathrm{y}_{2}, \mathrm{y}_{5}, \mathrm{y}_{7}$ and $\mathrm{y}_{9}$. The findings are line with the statement found by N. Mahantesh et al.2009. . It was observed from the study that majority percentage of respondent used Fungicide retailer (95\%) as sources of information of Fungicide dosages followed by Agriculture office (70\%).

\section{Conclusion, limitation and opportunity}

It can be concluded from the investigation that the majority 
of the respondent perception were high in the statements of "Prescribed dosages of fungicide application is best for control of fungus attack on crop field", "Chemical fungicide is environmentally friendly" and "Only used of Fungicide can control the entire fungus attack of the field". It may due to more involvement of the respondent on agriculture activity and contact with different govt. and private organization or other factor. It was also concluded from the survey that respondent perception were low in case of "Fungicide apply at the time of above ETL" and "Fungicide is applied on the basis of agro climatic condition". It may due to majority of the respondents were low education status, low income or other factor. It was concluded from the study that there exist a positive and significant association between the variable of land holding $\left(\mathrm{x}_{5}\right)$ and perception statements of $y_{3}, y_{4}, y_{6}$ and negative and significant association of the perception statements of $\mathrm{y}_{1}, \mathrm{y}_{2}, \mathrm{y}_{5}, \mathrm{y}_{7}, \mathrm{y}_{8}$ and $\mathrm{y}_{9}$. It may due to more involvement on agriculture activity. The variables caste $\left(\mathrm{x}_{4}\right)$ had no significant association with any of the perception statements. The variable gender $\left(\mathrm{x}_{1}\right)$ had positive and significant association with the statements of $\mathrm{y}_{1}, \mathrm{y}_{2}, \mathrm{y}_{4}, \mathrm{y}_{6}$ and $\mathrm{y}_{7}$. It may due to more involvement of male farmer on fungicide application. The variable age $\left(\mathrm{x}_{2}\right)$ had positive and significant association with the statements of $\mathrm{y}_{4}, \mathrm{y}_{7}$ and $\mathrm{y}_{8}$ and negative and significant association with the statement of $y_{9}$. It may due to that younger respondent have more perceived on exact way of fungicide application and environmental conservation and older respondent more perceived on fungus infestation scenario in previous ten years. The variable education $\left(\mathrm{x}_{3}\right)$ had negative and significant association with the statements of $\mathrm{y}_{1} \mathrm{y}_{3}, \mathrm{y}_{5}, \mathrm{y}_{7}$ and $\mathrm{y}_{8}$ and positive and significant association with the statements of $y 6$ and $y_{9}$. It may due to that educated respondent more perceived on safe use of fungicide. The variables Annual income $\left(\mathrm{x}_{6}\right)$ had positive and significant association with the statements of $y_{4}, y_{6}$ and $y_{9}$ and negative and significant association with the statement of y1. It may due to high perceived on biodiversity conservation and low perceived on previous fungus infestation scenario at Gopalpur village. The variables family size $\left(\mathrm{x}_{7}\right)$ had positive and significant association with the statements of $\mathrm{y}_{4}$ and $\mathrm{y}_{6}$ and negative and significant association with the statements of $\mathrm{y}_{1}, \mathrm{y}_{2}, \mathrm{y}_{5}, \mathrm{y}_{7}$ and $\mathrm{y}_{9}$. It may due to higher involvement on agriculture activity and contact with different organization of the respondent belong to small size family. It was also clear from the study that fungicide retailer was play major role for fungicide dosage information provider to the respondents. The limitation of the study were [1] Perception may different on the different fungicide which was not included [2] Short time study, [3] Perception of fungicide use may different on different crop, [4] There are only nine number of perception statement included which was may not sufficient to judge the farmers perception on fungicide use. The opportunity of the future study is [1] Comparative analysis of the farmer perception of fungicide use on different crop, [2] Comparative analysis of the farmer perception among the different fungicide uses, [3] Role of different organization for sustainable environment generation and biodiversity conservation.

\section{References}

1. Davidson AR, Yantis S, Norwood M, Montano DE.Amount of Information about the Attitude Object and Attitude Behavior Consistency. Journal of Personality and Social Psychology. 1985;49(5):1184-1198.

2. Adesina AA, Zinnah MM. Technology characteristics, farmer perceptions and adoption decisions: a tobit model application in Sierra Leone. Agric. Econ. 1993;9(4):297-311. doi:10.1016/01695150(93)90019-9.

3. Lanyintuo A, Mekuria M. 2005 Modelling Agricultural Technology Adoption Using the Software STATA.CIMMYT-ALP Training Manual No. 1/2005 (Part Two). Harare, Zimbabwe: International Maize and Wheat Improvement Centre.

4. Tabi AJ, Vabi MB, Malaa DK. Adoption of Maize and Cassava Technologies in the Forest-Savannah Zone of Cameroon: Implications for Poverty Reduction. World Applied Sciences Journal. 2010;11(2):196-209.

5. Feder G, Just RE, Zilberman D. Adoption of Agricultural Innovations in Developing Countries: A Survey. Economic Development and Cultural Change. 1985;33(2):255-298.

6. Feder G, Slade R. The Acquisition of Information and Adoption of New Technology. American Journal of Agricultural Economics. 1984;66:312-320

7. Akramov TK. Decentralization, Agricultural Services and Determinants of Input Use in Nigeria. Discussion Paper 0094, IFPRI. 2009.

8. Mahantesh N, Singh Alka. A Study on Farmers' Knowledge, Perception and Intensity of Pesticide Use in Vegetable Cultivation in Western Uttar Pradesh. PusaAgri Science. 2009;32:63-69.

9. Indira Devi P. Health Risk Perceptions, Awareness and Handling Behavior of Pesticides by Farm Workers. Agricultural Economics Research Review. 2009;22:263-268.

10. Shetty PK, Murugan M, Hiremath M, Sreeja KG. Farmers' education and perception on pesticide use and crop economies in Indian agriculture, Journal of Experimental Sciences. 2010;1(1):3-8.

11. Gibson JJ. 2010 Perception as a Function of Stimulation, in Psychology: A Study of Science, (ed.) Sigmund Koch. McGraw-Hill, New York. http://dx.doi.org/10.1037/0022-3514.49.5.1184.

12. Rahman S. Farm-level pesticide use in Bangladesh: determinants and awareness. Agriculture Ecosystems \& Environment. 2003;95(1):241252. doi: 10.1016/S0167-8809(02)00089-0.

13. Ntow WJ, Gijzen HJ, Kelderman P, Drechsel P. Farmer perceptions and pesticide use practices in vegetable production in Ghana. Pest Management Science. 2006;62(4):356-365. doi: Doi 10.1002/Ps.1178.

14. Ngowi A, Mbise T J, Ijani ASM, London L, Ajayi OC. Smallholder vegetable farmers in Northern Tanzania: Pesticides use practices, perceptions, cost and health effects. Crop Protection. 2007;26(11):1617-1624. doi: DOI 10.1016/j.cropro.2007.01.008.

15. Berg H. Pesticide use in rice and rice-fish farms in the Mekong Delta, Vietnam. Crop Protection. 2001;20(10):897-905. Doi: 10.1016/ S0261-2194(01)00039-4. 